\title{
ANALYZING THE IMPACTS OF SOCIOECONOMIC FACTORS ON NUTRITIONAL DIET IN PAKISTAN USING COMPOSITIONAL DATA ANALYSIS (CODA)
}

\author{
AMJAD, M. ${ }^{*}$ - AKBAR, M. - KHAN, M. S. R. - NOOR, F. - UlLAH, H. \\ Department of Mathematics and Statistics, Faculty of Basic and Applied Sciences, International \\ Islamic University, 44000 Islamabad, Pakistan \\ *Corresponding author \\ e-mail: amjaduaar.bkk@gmail.com; phone: +92-333-890-4769 \\ (Received 22 ${ }^{\text {nd }}$ May 2019; accepted $9^{\text {th }}$ Sep 2019)
}

\begin{abstract}
This study is conducted to analyze the effect of socioeconomic factors on households' diet pattern w.r.t shares of calorie intakes from protein, fat and carbohydrate in Pakistan. Cross sectional data are taken from a national level survey i.e. Household Integrated Income and Consumption survey (HIICS) 2015-2016. Compositional Data analysis (CODA) regression approach is followed to compare the effects of explanatory variables on share of calorie intakes from protein versus share of calorie intakes from fat and share of calories intake from carbohydrate versus shares of calories intake from protein and fat. Moreover, elasticities of macronutrient shares from household income, household size, dependency ratio and wealth index are also computed. The model's results explore that rising households' income causes an increase in fat consumption and a decrease in protein and carbohydrate consumption. The household size and rural areas are important factors increasing fat consumption to a higher degree than protein and carbohydrate consumption. Our findings matched with existing literature and they have the benefit to help the substitution effects between macronutrients in the setting of nutrition change. This study is very helpful to know the importance of healthy dietary balance and to avoid the non-communicable diseases as obesity and heart diseases at household level of Pakistan.
\end{abstract}

Keywords: calories, macronutrient shares, elasticity, ternary diagram, regression model

\section{Introduction}

Macronutrients are required in diet, as each makes energetic functions in the body by providing energy (calories). Each of the macronutrients, i.e. carbohydrate, protein, and fat, has different properties that affect health but all are considered source of energy. The optimum stability of their dietary contribution has been a topic of discussion for many years (Carreiro et al., 2016) and unbalance in the proportion of these macronutrients may increase the risk of chronic diseases and obesity. For a given calorie intakes, if one macronutrient share increases, then one or more other macronutrient shares decrease definitely. For instance, a diet containing high fat would be low in carbohydrate or protein. Hence, unbalance shares of macronutrients consumption may adversely affect Body mass index (BMI) (Miller et al., 1990; Ahluwalia et al., 2009; Austin et al., 2011 and Satia et al., 2002). Furthermore, the acceptable macronutrient distribution ranges (AMDR) for healthy adults are given as $20-35 \%, 45-65 \%, 10-35 \%$ shares of energy from fat, carbohydrate and protein respectively to minimize the risk of coronary heart diseases, diabetes, and obesity recommended by the Food and Nutrition Board of the Institute of Medicine (Institute of Medicine, 2005). The risk of non-communicable diseases (NCD) may increase when the shares of these macronutrients are out of these acceptable rages. Overall, the NCD contributed $63 \%$ of the total 57 million deaths in 2008 and nearly $80 \%$ of these NCD related deaths occurred in developing countries (WHO, 2010). Previous studies show 
that obesity is an important cause of NCD and can lead to severe cardiovascular morbidity and early deaths. The prevalence of obesity has increased globally during the past 30 years due to macronutrients malnutrition (Swinburn et al., 2011 and WHO, 2018). As a result of imbalance diet in term of macronutrients shares, overweight and obesity are increasing in developing countries. Protein-energy malnutrition is the most significant risk factor for diseases and deaths which particularly affects hundreds of millions of pregnant women and young children (Olaf and Michael, 2005). Lowcarbohydrate, high-protein diets can be a better choice for weight loss, increased satiety, and improved metabolic parameters (Kushner and Doerfler, 2008).

Pakistan is among the countries with high prevalence of obesity (Tanzil and Jamali, 2016). Findings of Satti and Khalid (2019) show that overweight and obesity prevalence is $21 \%$ and $9 \%$ respectively in Pakistani adults. According to WHO, $46 \%$ of all deaths in 2008 with estimated deaths in males and females of around 380,000 and 300,000 respectively are due to NCD in Pakistan (WHO, 2013). According to estimates of global disease burden research, Pakistan ranks $9^{\text {th }}$ among 188 countries in obese population (Ng, et al., 2014) and 40\% of reproductive age Pakistani women are either overweight or obese (NIPS and ICF, 2013). Hence, health situation is alarming in Pakistan due to rising obesity and all other Non-communicable diseases. To overcome this alarming situation, public health policy may be helpful for balancing of diet and of macronutrient shares. It requires to understand the factors affecting diet pattern in term of macronutrient shares at household level in Pakistan.

In order to estimate the association between nutrient intakes and socioeconomic factors, various regression models are frequently used with the different regressors and the different nutrients and calories intakes as response variables (Liaskos and Lazaridis, 2003; You et al., 2016; Akerele et al., 2014; Iyangbe and Orewa, 2009; Zhou, et al., 2018 and Trinh, et al., 2018). All the previous studies in Pakistan explain the importance of macronutrients consumption or volumes from food items. For example (Shabnam et al., 2016) show that the calorie and macronutrient consumption at household level depend upon food prices in Pakistan. Khattak and Khan (2009) explore imbalance energy intakes w.r.t macronutrients in female students of Pakistan. Shakoor et al., (2017) show that the majority of Pakistani female students had low consumption of macronutrients than recommended levels except fat.

To the best of authors' knowledge, no study has been conducted to analyze the factors affecting unbalance diet pattern in term of macronutrients shares at household level in Pakistan. Hence, major objective of this study is to fill this gap in literature by analyzing the impact of some important factors on macronutrient shares in energy intake at household level in Pakistan. This study is conducted to fill this research gap in the literature of food security in Pakistan. Moreover, Compositional data analysis (CODA) is considered instead of conventional regression inference to analyze macronutrients shares as the response variable and to avoid the problem of unbalance diet. CODA is known as a well traditional area of statistics with various areas of application, such as geology or economics (Egozcue et al., 2011; Pawlowsky-Glahn et al., 2015). This CODA technique has been applied recently in the field of nutritional and medical epidemiology (Dumuid et al., 2018; Leite, 2016; Mert et al., 2018). Hence, CODA technique is considered to analyze the phenomenon under consideration. Rest of the article contains material and methods, results, discussion and concluding remarks in the following sections. 


\section{Materials and methods}

Materials and methods consists of three sub-sections, i.e. theoretical framework and specification of model, data and description of variables, and methodology of analysis.

\section{Theoretical framework and model's specification}

To investigate the impact of socio-economic factors and households characteristics on the Nutrition status or macronutrients intake follows the conceptual frame work (world food program, 2012) of food and nutrition security at household level which is the extension of UNICEF (1991) and Smith and Haddad (2000). This conceptual frame work is the composition of three main layers of causes, i.e. immediate causes, underlying causes and basic causes and each comprises of different factors. The factors at basic causes affect the factors at underlying causes which in turn influence the factors at immediate causes. Our response variable is macronutrient intakes which belongs to immediate level causes whereas the explanatory variables are taken from other two layers of causes in the conceptual frame work. Thus, the theoretical model of macronutrients shares is specified as follows:

$$
M_{i}=\beta_{0}+\beta^{\prime} X^{\prime}+\varepsilon_{i}
$$

where $M_{i}$ shows the shares of macronutrients from total energy intakes of ith households, $\beta_{0}$ represents constant term, $\beta^{s}$ is the vector of slopes and $X^{v}$ is vector of explanatory variables while $\varepsilon_{i}$ is the error term.

\section{Data and description of variables}

This study uses data taken from Household integrated income and consumption survey (HIICS) 2015-2016 published by Pakistan Bureau of Statistics. This survey was collected in 2015-2016 by applying two stage stratified random sampling technique. Its sample comprises of 24238 households from all the four provinces of Pakistan. However, our sample size for this study is 14948 households due to non-availability of data regarding some variables. In this survey quantities of 72 food items are given from different food groups like meat, fish, milk, cheese, eggs, fresh fruits, dry fruits, vegetables (fresh/chilled/frozen/dried), sugar, jam, honey, chocolate \& confectionery, condiments and spices (whole and powder), non-alcoholic beverages, readymade food eaten out of home, public places, offices, bread \& cereals, and edible oils.

We calculate total calorie intake (in Kcal), protein and fat intakes (in grams) per day from all consumed food items for each household using Food Consumption table for Pakistan (Khan et al., 2001). The amount of protein and fat in grams are converted into calories for each household by multiplying 4 and 9 respectively (Trinh et al., 2018). Then we compute per capita calorie consumption (namely $\mathrm{Cal}_{P}$ ), per capita volume of calories calculated from protein $V_{p}$, and per capita volume of calories calculated from fat $V_{F}$ as follows. An per capita calorie consumption $\left(\mathrm{Cal}_{p}\right)$ is calculated by dividing the total consumption of calories per day by an adult equivalence conversion factor (AE) computed for each household. An adult equivalence conversion factor is the ratio between calorie requirement of individual according to age and the estimated adult reference value (Claro, et al., 2010). Similarly, per capita calories from fat and protein are computed for each household using the above procedure. Three types of macronutrients (Fat, protein and carbohydrate) are the source of total calorie intakes per capita, so the following 
relation exist between total per capita calorie intakes and macronutrients which help to calculate the per capita volume of calorie intake calculated from carbohydrate $V_{c}$

$$
\begin{gathered}
1 \text { gram protein }=4 \mathrm{kcal} \\
1 \text { gram Fat }=9 \mathrm{kcal} \\
\mathrm{V}_{\mathrm{P}}=4 \times \text { Protein in grams } \\
V_{\mathrm{F}}=9 \times \text { Fat in grams } \\
\mathrm{Cal} p=\mathrm{V}_{\mathrm{F}}+\mathrm{V}_{\mathrm{p}}+\mathrm{V}_{\mathrm{C}} \\
\mathrm{V}_{\mathrm{C}}=\mathrm{Cal} \mathrm{l}_{\mathrm{p}}-\mathrm{V}_{\mathrm{P}}-\mathrm{V}_{\mathrm{F}} \\
\mathrm{AE}=\frac{\text { Total calorie intakes of household per day }}{\text { AE }} \\
\text { Requirement of individual according to age }
\end{gathered}
$$

The shares of macronutrient $S_{F}, S_{P}$ and $S_{C}$ are defined as proportion of calorie from fat, protein and carbohydrate respectively as follows.

$$
S_{F}=\frac{V_{F}}{C a l_{p}}, S_{P}=\frac{V_{P}}{C a l_{P}}, S_{C}=1-S_{F}-S_{P}
$$

Some socioeconomic and demographic factors are taken as explanatory variables on the basis of the theoretical framework while considering availability of data. These explanatory variables include residential status, marital status of household head, paid employment dummies of father, mother and couple, Provinces dummies of Punjab, Sindh, Khyber Pakhtunkhwa (KPK) and Baluchistan, household head age, family size, dependency Ratios, dummies of livestock, own cultivation and Benazir income support programme (BISP), per capita income and education dummies of father and mother like no education, primary education, middle education and high education. The description of all the variables used by the study is given in Table 1 whereas Table 2 presents descriptive statistics of the variables.

Table 2 shows that the total number of calories per capita is 2451.5 calories which mean that, while households of Pakistan fulfil their calories requirement according to FAO (2013) is 2440 calories per person. Descriptive results show that 626.7, 283.66 and 1541.2 calories come from the Fat, protein and carbohydrate respectively. The sum of the volumes of calories from these three macronutrients equal to 2451.5 calories. The shares of calories from Fat, protein and carbohydrate are $25.9 \%, 11.4 \%$, and $62.7 \%$ respectively and Table 2 also represents the percentages of all categories of Categorical variables which included for the analysis.

\section{Methodology of analysis}

Methodology of analysis consists of two sub sections i.e. introduction to CODA, and compositional regression model to explain macronutrient shares. 
Table 1. Description of the variables

\begin{tabular}{|c|c|c|c|c|c|}
\hline Notations & Variables label & Description & Notations & Variables label & Description \\
\hline $\mathrm{Cal}_{p}$ & Calories volume & $\begin{array}{l}\text { Calories per } \\
\text { capita }\end{array}$ & $E M_{i}^{C}$ & $\begin{array}{l}\text { Couple paid } \\
\text { employment }\end{array}$ & $\begin{array}{c}\text { Couple paid } \\
\text { employment }=1 \\
\& \text { zero otherwise }\end{array}$ \\
\hline$V_{F}$ & Fat volume & $\begin{array}{l}\text { Number of } \\
\text { calories from fat }\end{array}$ & $V_{p}$ & Protein volume & $\begin{array}{l}\text { Number of } \\
\text { calories from } \\
\text { protein }\end{array}$ \\
\hline$S_{F}$ & Fat shares & $\begin{array}{c}\text { Shares of calories } \\
\text { from fat }\end{array}$ & $V_{C}$ & $\begin{array}{l}\text { Carbohydrate } \\
\text { volume }\end{array}$ & $\begin{array}{l}\text { Number of } \\
\text { calories from } \\
\text { carbohydrate }\end{array}$ \\
\hline$S_{C}$ & $\begin{array}{l}\text { Carbohydrate } \\
\text { shares }\end{array}$ & $\begin{array}{c}\text { Shares of calories } \\
\text { from } \\
\text { carbohydrate }\end{array}$ & $S_{p}$ & Protein shares & $\begin{array}{l}\text { Shares of calories } \\
\text { from protein }\end{array}$ \\
\hline Size $_{\mathrm{i}}$ & Household size & $\begin{array}{l}\text { Number of } \\
\text { family members } \\
\text { in the household }\end{array}$ & $E M_{i}^{m}$ & $\begin{array}{l}\text { Maternal paid } \\
\text { employment }\end{array}$ & $\begin{array}{c}\text { Mother paid } \\
\text { employment }=1 \\
\& \text { zero otherwise }\end{array}$ \\
\hline$I_{i}$ & $\begin{array}{c}\text { Monthly income } \\
\text { of household }\end{array}$ & $\begin{array}{c}\text { Total monthly } \\
\text { income in rupees }\end{array}$ & $E M_{i}^{p}$ & $\begin{array}{l}\text { Paternal paid } \\
\text { employment }\end{array}$ & $\begin{array}{c}\text { Father paid } \\
\text { employment }=1 \\
\& \text { zero otherwise }\end{array}$ \\
\hline $\operatorname{Res}_{i}$ & $\begin{array}{l}\text { Residential } \\
\text { status }\end{array}$ & $\begin{array}{c}\text { Rural }=1 \& \text { zero } \\
\text { otherwise }\end{array}$ & $E_{i}^{m p}$ & $\begin{array}{l}\text { Maternal } \\
\text { primary } \\
\text { education }\end{array}$ & $\begin{array}{c}\text { Mother primary } \\
\text { education }=1 \& \\
\text { zero otherwise }\end{array}$ \\
\hline$A g \theta_{i}^{h}$ & $\begin{array}{c}\text { Age of } \\
\text { household head }\end{array}$ & $\mathrm{HH}$ age in years & $E_{\mathrm{i}}^{\mathrm{mm}}$ & $\begin{array}{c}\text { Maternal middle } \\
\text { education }\end{array}$ & $\begin{array}{l}\text { Mother middle } \\
\text { education }=1 \& \\
\text { zero otherwise }\end{array}$ \\
\hline $\operatorname{Mar}_{\mathbb{i}}^{H}$ & $\begin{array}{l}\text { HH marital } \\
\text { status }\end{array}$ & $\begin{array}{l}\text { HH married }=1 \\
\& \text { zero otherwise }\end{array}$ & $E_{i}^{m h}$ & $\begin{array}{l}\text { Maternal high } \\
\text { education }\end{array}$ & $\begin{array}{c}\text { Mother high } \\
\text { education }=1 \& \\
\text { zero otherwise }\end{array}$ \\
\hline$L_{\mathrm{i}}$ & $\begin{array}{l}\text { Ownership of } \\
\text { livestock }\end{array}$ & $\begin{array}{l}\text { Household's } \\
\text { ownership of } \\
\text { livestock }=1 \& \\
\text { zero otherwise }\end{array}$ & $E_{i}^{p p}$ & $\begin{array}{l}\text { Paternal primary } \\
\text { education }\end{array}$ & $\begin{array}{l}\text { Paternal primary } \\
\text { education }=1 \& \\
\text { zero otherwise }\end{array}$ \\
\hline$P_{\mathrm{i}}^{h p}$ & KPK origin & $\begin{array}{c}\text { Household's } \\
\text { origin of } \\
\text { KPK }=1 \text { \& zero } \\
\text { otherwise }\end{array}$ & $E_{\mathrm{i}}^{p m}$ & $\begin{array}{l}\text { Paternal middle } \\
\text { education }\end{array}$ & $\begin{array}{l}\text { Paternal middle } \\
\text { education }=1 \& \\
\text { zero otherwise }\end{array}$ \\
\hline$P_{i}^{p}$ & Punjab origin & $\begin{array}{l}\text { Punjab origin }=1 \\
\& \text { zero otherwise }\end{array}$ & $E_{i}^{p h}$ & $\begin{array}{l}\text { Paternal high } \\
\text { education }\end{array}$ & $\begin{array}{l}\text { Paternal high } \\
\text { education }=1 \& \\
\text { zero otherwise }\end{array}$ \\
\hline$P_{\mathrm{i}}^{g}$ & Sindh origin & $\begin{array}{l}\text { Sindh origin }=1 \\
\& \text { zero otherwise }\end{array}$ & $W_{\mathrm{i}}$ & Wealth index & $\begin{array}{l}\text { Wealth index of } \\
\text { households }\end{array}$ \\
\hline$C_{\tilde{i}}$ & $\begin{array}{c}\text { Households' } \\
\text { cultivation of } \\
\text { agricultural land }\end{array}$ & $\begin{array}{c}\text { Household } \\
\text { involve in } \\
\text { cultivation }=1 \& \\
\text { zero otherwise }\end{array}$ & $D R_{\mathrm{i}}$ & $\begin{array}{l}\text { Dependency } \\
\text { ratio }\end{array}$ & $\begin{array}{c}\text { Dependency ratio } \\
\text { of households }\end{array}$ \\
\hline
\end{tabular}


Table 2. Descriptive statistics of variables

\begin{tabular}{|c|c|c|}
\hline Variables & Description & Mean/(SD)/Percentage \\
\hline Cal & Number of calories per capita & $2451.5(900.43)$ \\
\hline$V_{F}$ & Number of calories from fat & $626.7(281.8)$ \\
\hline$V_{p}$ & Number of calories from protein & $283.6(121.6)$ \\
\hline$V_{c}$ & $\begin{array}{c}\text { Number of calories from } \\
\text { carbohydrate }\end{array}$ & $1541.1(630.5)$ \\
\hline$S_{F}$ & Shares of calories from fat & $25.9 \%(8.1 \%)$ \\
\hline$S_{p}$ & Shares of calories from protein & $11.4 \%(1.8 \%)$ \\
\hline$s_{c}$ & $\begin{array}{l}\text { Shares of calories from } \\
\text { carbohydrate }\end{array}$ & $62.7 \%(8.7 \%)$ \\
\hline $\operatorname{Res}_{\mathrm{i}}$ & $\begin{array}{c}\text { Residential status } \\
0=\text { Urban } \\
1=\text { Rural }\end{array}$ & $\begin{array}{l}74.8 \% \\
25.2 \%\end{array}$ \\
\hline $\operatorname{Mar}_{\mathfrak{i}}^{H}$ & $\begin{array}{c}\text { Marital status of household head } \\
0=\text { Unmarried } \\
1=\text { Married }\end{array}$ & $\begin{array}{l}10.1 \% \\
89.9 \%\end{array}$ \\
\hline$L_{\mathrm{i}}$ & $\begin{array}{c}\text { Livestock } \\
0=\text { No } \\
1=\text { Yes } \\
\end{array}$ & $\begin{array}{c}99 \% \\
1 \%\end{array}$ \\
\hline$c_{i}$ & $\begin{array}{c}\text { Own cultivation } \\
0=\text { No } \\
1=\text { Yes }\end{array}$ & $\begin{array}{l}92.47 \% \\
7.53 \%\end{array}$ \\
\hline$E M_{\mathrm{i}}^{p}$ & $\begin{array}{c}\text { Paternal paid employment } \\
0=\text { No } \\
1=\text { Yes }\end{array}$ & $\begin{array}{l}40.23 \% \\
59.77 \%\end{array}$ \\
\hline$E M_{i}^{M}$ & $\begin{array}{c}\text { Maternal paid employment } \\
0=\text { No } \\
1=\text { Yes }\end{array}$ & $\begin{array}{l}91.13 \% \\
8.87 \%\end{array}$ \\
\hline$E M_{i}^{C}$ & $\begin{array}{c}\text { Couple paid employment } \\
0=\text { No } \\
1=\text { Yes } \\
\end{array}$ & $\begin{array}{l}95.54 \% \\
5.46 \%\end{array}$ \\
\hline$P_{\mathrm{i}}$ & $\begin{array}{c}\text { Province } \\
0=\text { Baluchistan } \\
1=\text { Punjab } \\
2=\text { Sindh } \\
3=\text { KPK }\end{array}$ & $\begin{array}{c}8.7 \% \\
45.24 \% \\
27.05 \% \\
19.01 \% \\
\end{array}$ \\
\hline$E_{i}^{p}$ & $\begin{array}{c}\text { Paternal education } \\
0=\text { No education } \\
1=\text { Primary education } \\
2=\text { Middle education } \\
3=\text { High education }\end{array}$ & $\begin{array}{c}7.59 \% \\
37.42 \% \\
51.73 \% \\
3.26 \% \\
\end{array}$ \\
\hline$E_{i}^{M}$ & $\begin{array}{c}\text { Maternal education } \\
0=\text { No education } \\
1=\text { Primary education } \\
2=\text { Middle education } \\
3=\text { High education }\end{array}$ & $\begin{array}{c}46.89 \% \\
24.19 \% \\
27.34 \% \\
1.58 \%\end{array}$ \\
\hline
\end{tabular}




\section{Introduction to CODA}

We can not apply traditional methods of regression when the dependent or independent variable consists of a vector of shares (Aitchison, 1982; Pawlowsky-Glahn, et al., 2015) because these shares are positive real numbers and carry relative information with constant sum (Chen et al., 2017). In the previous studies, many types of models are used to apply regression with shares (Morais et al., 2018). When a vector of shares (e.g. the shares of macronutrients) is the response variable and other regressors are traditional quantitative or qualitative variables, a proposed model known as CODA (compositional data analysis) is considered as the valid modelling technique (Trinh et al., 2018, Egozcue et al., 2011, Pawlowsky-Glahn et al., 2015, Aitchison, 1986). This model depends on a log-ratio transformation of shares. In the simplex space $S^{D}$, a composition $\mathrm{S}$ of $\mathrm{D}$ shares can be denoted as

$$
S^{D}=\left\{S=\left(S_{1}, S_{2} \ldots \ldots \ldots \ldots \ldots \ldots, S_{D}\right)^{n}=S_{j}>0, j=1, \ldots D_{;} ; \Sigma_{j=1}^{D} S_{j}=1\right\}
$$

It is interesting to know that if the total sum of these fitted shares equal to one, then we cannot apply classical regression models directly. These shares are therefore converted using the transformation of an isometric log-ratio (ILR) (Egozcue et al., 2003) (for example) in D-1 coordinates which can be denoted in the classical Euclidean space so that the linear regression models can be applied separately to the D-1 coordinates. These coordinates of ILR are explained as follows (Trinh et al., 2018):

$$
i l r(S)=W^{v} \log (S)=S^{*}=\left(S^{*} \ldots \ldots S^{*}{ }_{D-1}\right)^{x}
$$

where W defined as the $D \times(D-1)$ contrast matrix (Chen et al., 2017) which helps the forecasting of shares on the orthogonal basis of $S^{D}$. For instance, we have $\mathrm{D}=3$, it is possible to use the following contrast matrix (this matrix used by the function "illr" in $\mathrm{R}$ package "Composition"):

$$
W=\left[\begin{array}{cc}
-\frac{1}{\sqrt{6}} & -\frac{1}{\sqrt{2}} \\
-\frac{1}{\sqrt{6}} & \frac{1}{\sqrt{2}} \\
\sqrt{\frac{2}{3}} & 0
\end{array}\right]
$$

Guiding to the following two ILR coordinates of $S=\left(S_{1}, S_{2}, S_{a}\right)$ :

$$
\begin{gathered}
S^{*}{ }_{1}=\frac{1}{\sqrt{2}} \log \frac{S_{z}}{S_{1}} \\
S^{*}=\frac{2}{\sqrt{6}} \log \frac{S_{3}}{\sqrt{S_{2} S_{1}}}
\end{gathered}
$$

In this shape, the first ILR coordinate $S^{*}$ protein shares have all the relative data of $S_{2}$ compared to the fat shares. Similarly, the second ILR coordinate $S_{2}^{*}$ carbohydrate shares have all the data of $S_{a}$ compared to the geometric mean respectively of the remaining protein and fat shares (Muller et al., 2016). At the end, with the help of the inverse 
transformation to go back to the simplex to interpret the shares model. This inverse transformation is defined as

$$
i l r^{-1}\left(S^{*}\right)=C\left(\exp \left(W S^{*}\right)\right)^{*}
$$

Here, $\mathrm{C}($.) denote the closure operation which permitting to go from a vector of volumes $\mathrm{V}$ to a vector of shares $\mathrm{S}$

$$
C\left(V_{1}, \ldots, V_{D}\right)^{p}=\left(\frac{V_{1}}{\sum_{j=1}^{D} V_{j}}, \ldots \ldots, \frac{V_{D}}{\sum_{j=1}^{D} V_{j}}\right)^{n}=\left(S_{1} \ldots \ldots, S_{D}\right)^{b} .
$$

\section{Compositional regression model for macronutrient shares}

We want to check the impact of socioeconomic factors and household characteristics of Pakistani households on macronutrient composition. Equation 1 can be written as an adapted compositional regression model as follows (Trinh et al., 2018):

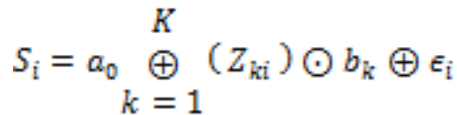

$$
\begin{aligned}
& S_{i}=a_{0} \oplus A g e_{i}^{h} \odot b_{1} \oplus S i z e_{i} \odot b_{2} \oplus \operatorname{Res}_{i} \odot b_{a} \oplus M a r_{i}^{H} \odot b_{4} \\
& \oplus P_{i}^{\mathrm{hp}} \odot b_{5} \oplus P_{i}^{p} \odot b_{6} \oplus P_{i}^{g} \odot b_{7} \oplus I_{i} \odot b_{9} \oplus E M_{i}^{q} \odot b_{9} \oplus E M_{i}^{\mathrm{m}} \odot b_{10} \oplus E M_{i}^{p} \odot b_{11} \\
& \oplus E_{i}^{m p} \odot b_{12} \oplus E_{i}^{m m} \odot b_{13} \oplus E_{i}^{m h} \odot b_{14} \oplus E_{i}^{p p} \odot b_{15} \oplus E_{i}^{p m} \odot b_{16} \oplus E_{i}^{p h} \odot b_{17} \oplus \\
& L_{i} \odot b_{18} \oplus D R_{i} \odot b_{19} \oplus W_{i} \odot b_{20} \oplus C_{i} \odot b_{21} \epsilon_{i}
\end{aligned}
$$

In Equation 2, $S=\left(S_{F} S_{p r} S_{C}\right)^{g} i$ represents the ith households and $Z_{k}$ are classical regressors as $\operatorname{Res}_{\mathrm{i}}, \operatorname{Mar}_{i}^{H}, P_{i}^{k p}, P_{i}^{p}, P_{i}^{g}, E M_{i}^{c}, E M_{i}^{m}, E M_{i}^{p}, E_{i}^{m p}, E_{i}^{m m}, E_{i}^{m h}{ }_{n}^{m p} E_{i}^{p p}, E_{i}^{p m}, E_{i}^{p h}, L_{i_{i}}$ and $C_{i}$ are the dummy variables representing residential status, household head marital status, Khyber Pakhtunkhwa origin, Punjab origin, Sindh origin, couple paid employment, maternal paid employment, paternal paid employment, maternal primary, middle, and high education, paternal primary, middle, and high education, livestock and own cultivation respectively. $A g e_{i}^{h_{0}}, A g e_{i}^{g h}{ }_{,}{ }_{S i z e}, S_{i z} e_{i}^{2} I_{i}, D R_{i_{n}}$ and $W_{i}$ are the variables representing household head age, household head age square, household size, household size square, household total income, dependency ratio and wealth index respectively. Detailed explanation of the variables is provided in Table 1.

As in Dumuid et al. (2018), Muller et al. (2016) and Nguyen et al. (2018) for the fitting and interpretation of the model in Equation 2, we required to run $D-1=2$ ordinary linear regression model, i.e. one for every ILR coordinates of $S: S^{*}{ }_{1}$ and $S_{2}{ }_{2}$ for each period $\mathrm{j}=1,2$ (Egozcue et al., 2012).

$$
\begin{aligned}
& S_{j, i}^{*}=a_{0 j}^{*}+\sum_{k=1}^{K} b_{j, k}^{*} X_{k i} \check{n}_{j, i}^{*} \\
& S_{j, i}^{*}=a_{0 j}{ }^{*}+b^{*}{ }_{j, 1} \operatorname{Age}_{i}^{h}+b^{*}{ }_{j, 2} \operatorname{Size}_{i}+b^{*}{ }_{j, 3} \operatorname{Res}_{i}+b^{*}{ }_{j, 4} \operatorname{Mar}_{i}{ }^{H}+ \\
& b_{j, 5}^{*} P_{i}^{k p}+b_{j, 6}^{*} P_{i}^{P}+b_{j, 7}^{*} P_{i}^{S}+b^{*}{ }_{j, 8} I_{i}+b^{*}{ }_{j, 9} E M_{i}^{c}+b^{*}{ }_{j, 10} E M_{i}^{m}+ \\
& b^{*}{ }_{j, 11} E M_{i}^{p}+b^{*}{ }_{j, 12} E_{i}^{m p}+b^{*}{ }_{j, 13} E_{i}^{m m}+b^{*}{ }_{j, 14} E_{i}^{m h}+b^{*}{ }_{j, 15} E_{i}^{p p}+b^{*}{ }_{j, 16} E_{i}^{p m}+ \\
& b^{*}{ }_{j, 17} E_{i}^{p h}+b^{*}{ }_{j, 18} L_{i}+b^{*}{ }_{j, 19} D R_{i}+b_{j, 20}^{*} W_{i}+b^{*}{ }_{j, 21} C_{i}+\check{n}^{*}{ }_{j, i}
\end{aligned}
$$


where $a_{0 j}{ }^{*}, b^{*} j k, \epsilon_{j}^{*}$ are the $j^{\text {th }}$ ILR coordinates of $a_{0,} b_{k,} \varepsilon_{x}$

Since we fit the two transformed models in Equation 3 using the method of ordinary least square (OLS) and $\varepsilon^{*}$ is assumed to follow normal distribution. The model's parameters calculation in the simplex and Equation 2 can be obtained by using inverse transformation from the transformed model in Equation 3 computed parameters. For example:

$$
b_{2}^{n_{2}}=C\left(\exp \left(W b^{n_{*}}{ }_{2}\right)\right)^{n} \text {, where } b_{2}^{n_{2}}=\left(b_{1,2}^{n_{*}}, b^{n_{4}}{ }_{2,2}\right)^{s}
$$

All parameters are estimated in compositional regression model using the method of OLS. The value of compositional models can be assessed to the share data, called adjusted " $R{ }^{2 m}$ (Van den Boogaart and Tolosana-Delgado, 2013). The adjusted R-squared value shows that our compositional models explain about $11.87 \%$ and $12.54 \%$ of the total compositional data variability, respectively. To estimate the parameters of compositional regression model, the package "Compositions" in $\mathrm{R}$ language has been used. The R package " Plotly" used to make ternary diagrams.

\section{Results}

Results consist of three sub sections i.e. comparison of urban and rural households, results of compositional regression model and Elasticities of macronutrients shares.

\section{Comparison of urban and rural households}

Figure 1 displays that the overall households in our sample have on the average 2283 calories per capita per day which looks nearly equal to the requirement of (FAO). But the rural households consume on the average 2657.56 calories which is higher than urban households as well as overall average of households which is 2196.15 . We can see the clearly difference between the macronutrients shares in calories for both regions.

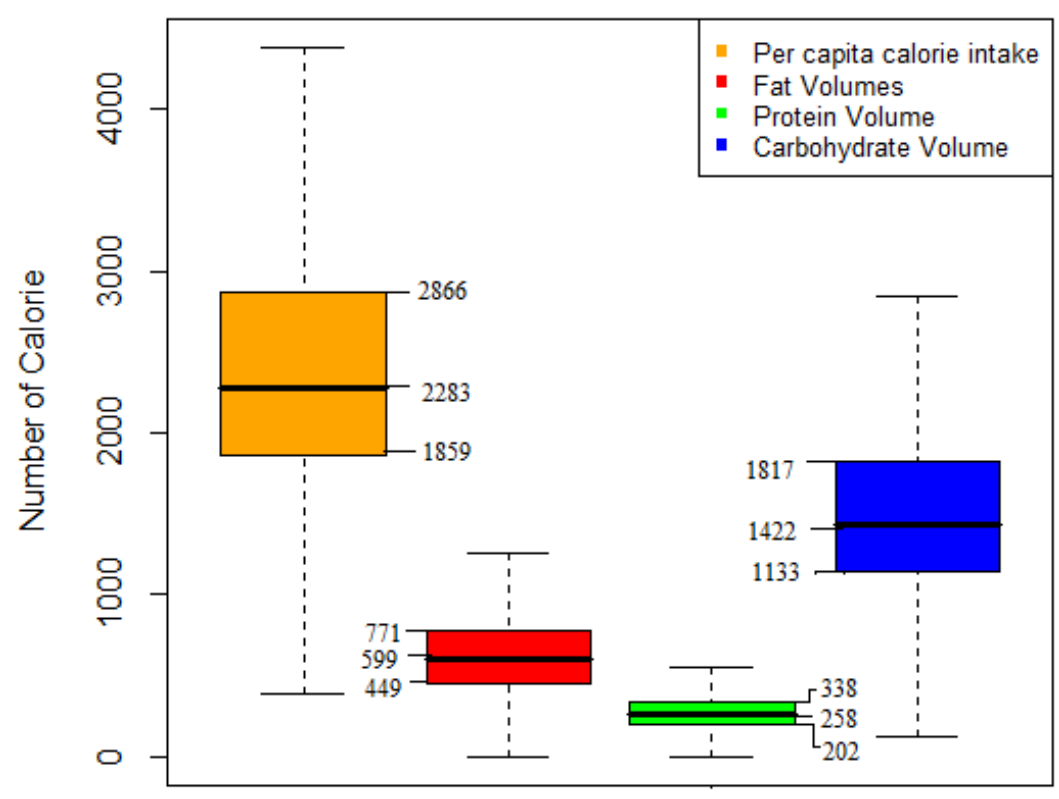

Figure 1. Per capita calorie intake and volume of macronutrients using overall households 
Figures 2 and 3 show the comparison of urban and rural site of per capita calorie intake and volume of macronutrient shares using box plot which bases on lower quartile, median and upper quartile. The rural region has the high median i.e. 2627.56 per capita calorie than urban region i.e. 2196.15 calories. Lower and upper quartiles of the rural households of calories are 2082.71 and 3370.31 respectively which are more than urban households i.e. 1807.82 and 2697.25 respectively. Similarly, all three macronutrient shares of rural site having greater values of lower, median and upper quartile compared to the urban households. According to Table 3, it is clear to see that there is significant difference between all variables of urban and rural areas.

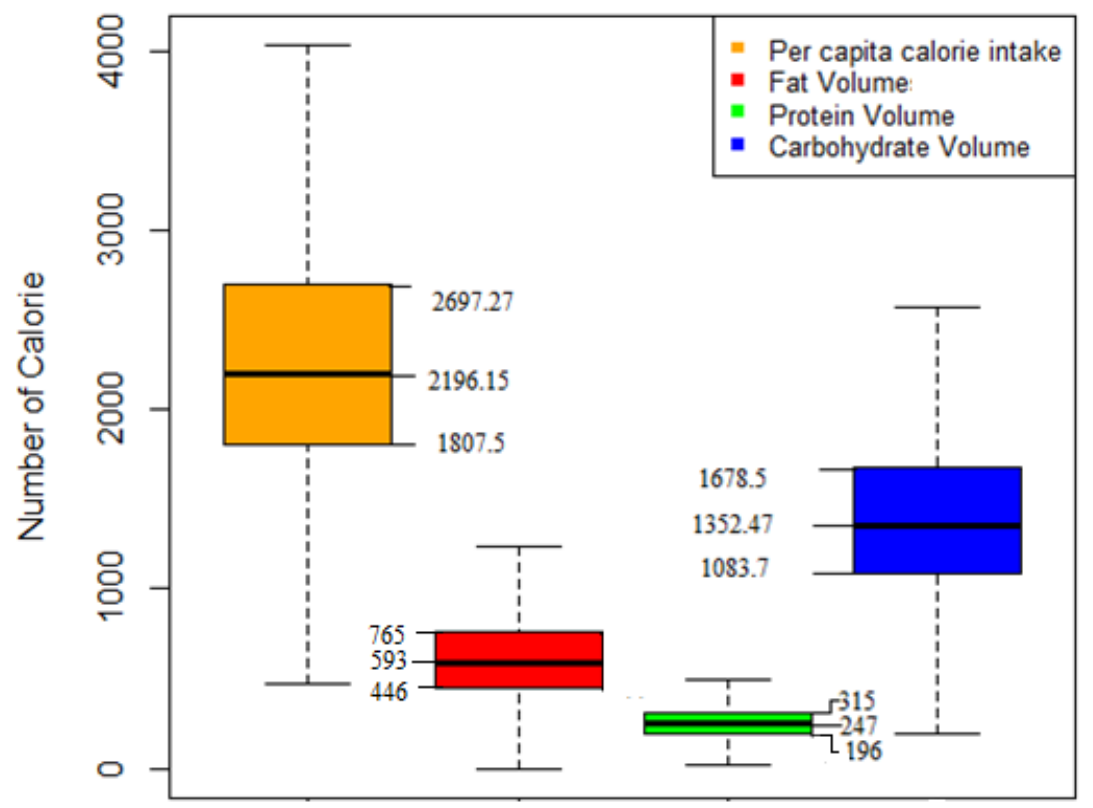

Figure 2. Per capita calorie intake and volume of macronutrients using urban site

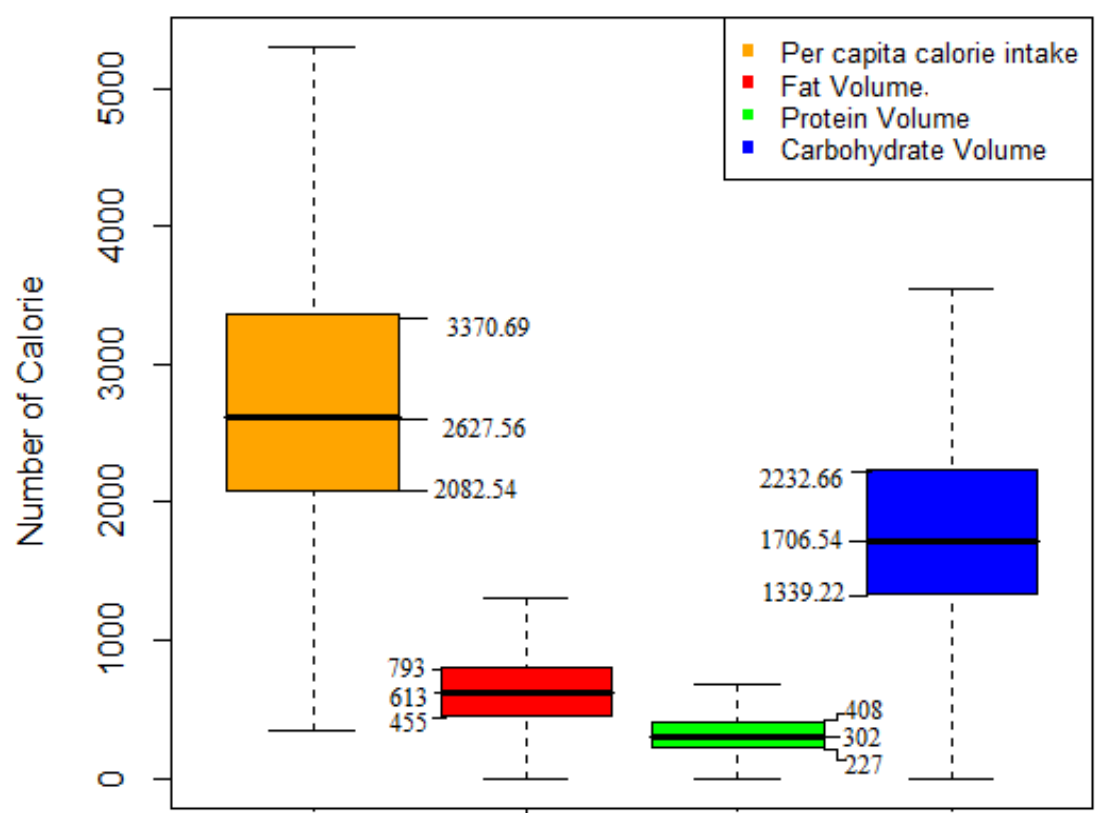

Figure 3. Per capita calorie intake and volume of macronutrients using rural site 
Table 3. Comparison of means using unpaired t test

\begin{tabular}{|c|c|c|c|c|c|c|}
\hline Variables & Region & Mean & $\begin{array}{l}\text { Standard } \\
\text { deviation }\end{array}$ & $\begin{array}{c}95 \% \text { confidence } \\
\text { interval }\end{array}$ & t-value & P-value \\
\hline \multirow{2}{*}{$\begin{array}{c}\text { Per capita } \\
\text { calorie intake }\end{array}$} & Urban & 2836.93 & 1079.13 & 2802.4-2871.4 & \multirow{2}{*}{26.94} & \multirow{2}{*}{0.0000} \\
\hline & Rural & 2321.813 & 790.68 & 2307.1-2336.4 & & \\
\hline \multirow{2}{*}{$\begin{array}{l}\text { Calories from } \\
\text { fat }\end{array}$} & Urban & 639.31 & 288.74 & $630.1-648.5$ & \multirow{2}{*}{3.12} & \multirow{2}{*}{0.0018} \\
\hline & Rural & 622.42 & 279.30 & $617.2-627.6$ & & \\
\hline \multirow{2}{*}{$\begin{array}{l}\text { Calories from } \\
\text { protein }\end{array}$} & Urban & 331.41 & 144.65 & $326.7-336.0$ & \multirow{2}{*}{24.84} & \multirow{2}{*}{0.0000} \\
\hline & Rural & 267.52 & 108.19 & $265.5-269.5$ & & \\
\hline \multirow{2}{*}{$\begin{array}{l}\text { Calories from } \\
\text { carbohydrate }\end{array}$} & Urban & 1866.1 & 764.9 & $1841.7-1890.6$ & \multirow{2}{*}{32.26} & \multirow{2}{*}{0.0000} \\
\hline & Rural & 1431.8 & 535.9 & $1421.9-1441.7$ & & \\
\hline
\end{tabular}

$H_{0}=$ there is no difference between means, versus $H_{A}=$ there is difference between means

Figure 4 represents the tri plot of three macronutrients shares in calories for urban households. This figure shows that most of the urban households have more than $30 \%$ shares of carbohydrate, but a few have $40 \%$ or below. According to this ternary diagram most of the urban households have less than $20 \%$ shares of protein in calories. It can be seen that most urban families have less than $60 \%$ shares of fat in calories. Figure 5 shows the ternary plot of macronutrient shares for rural households and this represents that all rural households have more than $40 \%$ shares of carbohydrate and less than $20 \%$ shares of protein. All households in the rural region have less than $60 \%$ shares of fat in calories. Moreover, $t$ test is employed to test the difference between means of calories intake, shares of calories intake from fat, protein and carbohydrate assuming that there are two independent samples consisting of rural and urban households. The results are reported in Table 3. All the $\mathrm{t}$ statistics are significant which shows that there is significant difference between rural and urban households w.r.t energy intake from the three macronutrients.

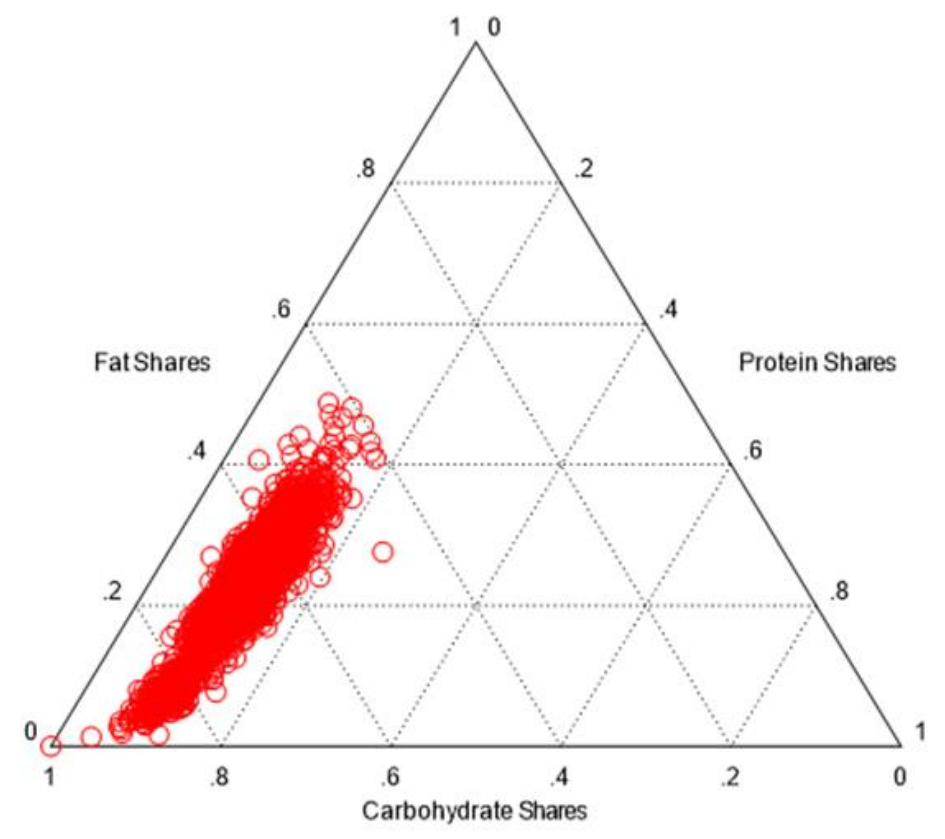

Figure 4. Ternary diagram of urban site 


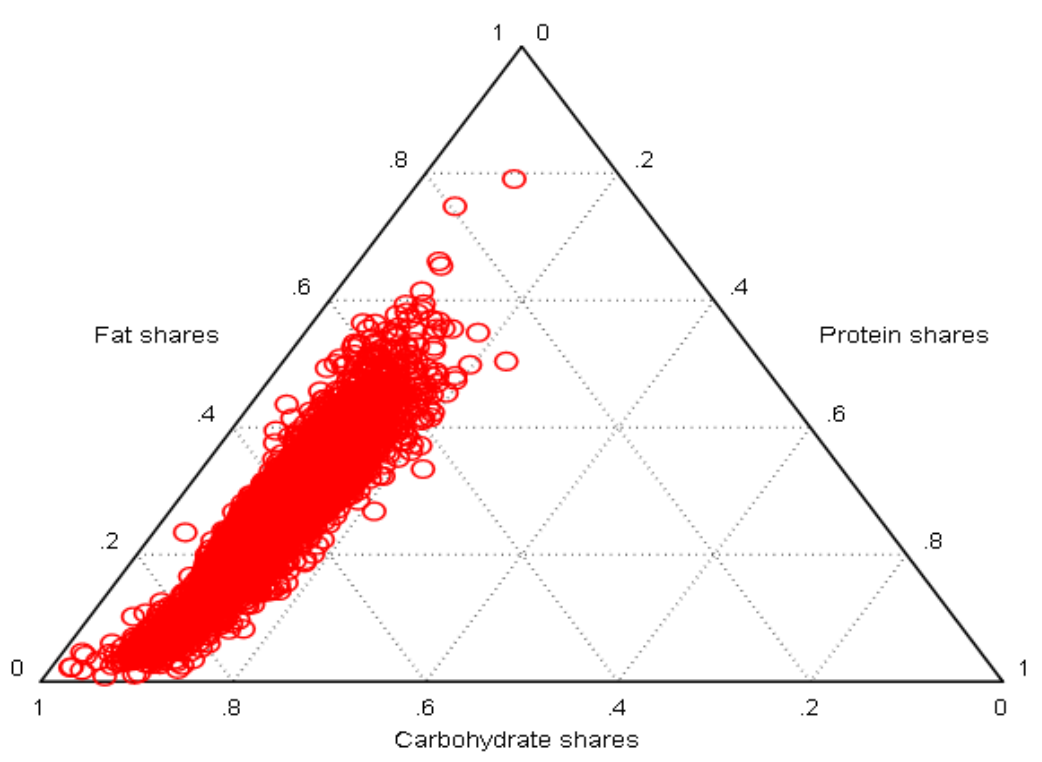

Figure 5. Ternary diagram of rural site

\section{Compositional regression model results}

We now fit a CODA regression model describing the impacts of socioeconomic factors on macronutrients shares using estimation method of OLS. The First isometric log ratio (ILR) coordinate compares protein against fat shares, while second ILR coordinate compares carbohydrate versus geometric mean of fat and protein shares. Tables 4 and 5 describe the parameters of the compositional model in ILR coordinates. The two ILR coordinates treated as response variables and associated with explanatory variables.

Estimation results given in Tables 4 and 5 are interpreted as (Trinh et al., 2018 and Dumuid et al., 2018). Table 4 shows the coefficients of first coordinate consisting of protein versus fat shares. Estimate of income shows that $1 \%$ rise of income for a given household causes decline of the relative dominance of protein versus fat share $\left(e^{0.0798}=1.083\right)$ approximately by $0.083 \%$. This analysis shows that rising household's income is not helpful to improve protein shares in calories than fat shares. Similarly, an increase of one more year of household head age, the relative dominance of protein share $\left(e^{0.00158}=1.0058\right)$ decreases approximate by $0.0058 \%$. The impact of household size and dependency ratio on the protein share as 1 more person increase of family member and dependency ratio then relative dominance of this first ILR coordinate $\left(e^{0.0105}=1.0105\right.$ and $\left.e^{0.1149}=1.13\right)$ increase approximately $0.0105 \%$ and $0.13 \%$ respectively to fat share. These results are in line with Trinh et al., (2018).

The first ILR coordinate is explained by residential status, hence $Z^{n \text { (protein })^{*}}{ }_{1}=1.56$ is the fitted value of the coordinate $Z^{\text {(protein ) }}{ }_{1}^{*}$ for rural while $Z^{n \text { (protein ) }}{ }_{1}^{*}=1.7696$ for urban. It means that the relative dominance of protein in the composition response is $\left(e^{1.56}=4.75\right)$ for rural and $\left(e^{1.7696}=5.8685\right)$ for urban. Further, it can be conclude that the relative dominance of protein for rural households is $e^{0.0628}=1.0648$ times greater than for urban households. Coefficient estimate of marital status of household head shows that a household with married head compared to a household with unmarried head would likely to have more share of protein versus fat. The relative dominance of protein shares for province Sindh is less than other provinces and dominance of protein shares for 
Khyber Pakhtunkhwa is 1.064 times greater than for other provinces compared to fat shares. Hence, the households of KPK compared to other households are likely to have more shares of calories obtained from protein than fat. Similarly, the relative domination of protein shares versus fat share for the households operating agricultural land and the households having livestock are 1.07 and 1.06 times greater than the households who are not operating agricultural land and the households who have not livestock. All educational dummies of maternal and paternal may not be helpful to improve protein shares compared to fat shares in the balanced diet. The households with education of maternal and paternal may increase their fat shares in the diet.

Table 4. Results of compositional regression model in ILR coordinate for protein versus fat shares

\begin{tabular}{|c|c|c|c|c|}
\hline \multicolumn{5}{|c|}{$S_{1}^{*}=\frac{1}{\sqrt{2}} \log \frac{S_{F}}{S_{F}}$ (protein versus fat shares) is response variable } \\
\hline Variables & Description & Coefficients & S. E. & P-value \\
\hline \multicolumn{2}{|r|}{ Intercept } & -0.22260 & 0.04268 & $0.0000 * * *$ \\
\hline$A g e_{i}^{h / 2}$ & Age of household head & -0.00158 & 0.00019 & $0.0000 * * *$ \\
\hline Size $_{\mathrm{i}}$ & Household size & 0.01058 & 0.00087 & $0.0000 * * *$ \\
\hline $\operatorname{Res}_{i}$ & Residential status & 0.06282 & 0.00563 & $0.0000 * * *$ \\
\hline $\operatorname{Mar}_{\mathbb{i}}^{H}$ & HH marital status & 0.02804 & 0.00773 & $0.0002 * * *$ \\
\hline$P_{\mathrm{i}}^{\mathrm{hp} p}$ & KPK province & 0.04640 & 0.00887 & $0.0000 * * *$ \\
\hline$P_{\mathrm{i}}^{p}$ & Punjab province & 0.01065 & 0.00816 & 0.19193 \\
\hline$P_{\mathbb{i}}^{S}$ & Sindh province & -0.02352 & 0.00850 & $0.00574 * * *$ \\
\hline$I_{i}$ & Monthly income of household & -0.07980 & 0.00847 & $0.0000 * * *$ \\
\hline$E M_{i}^{\mathcal{C}}$ & Couple paid employment & 0.01760 & 0.01486 & 0.23630 \\
\hline$E M_{i}^{\mathrm{m}}$ & Maternal paid employment & -0.01120 & 0.01199 & 0.34668 \\
\hline$E M_{i}^{p}$ & Paternal paid employment & -0.00410 & 0.00500 & 0.40955 \\
\hline$E_{i}^{m p}$ & Maternal primary education & -0.05890 & 0.00578 & $0.0000 * * *$ \\
\hline$E_{\mathrm{i}}^{\mathrm{mm}}$ & Maternal middle education & -0.02404 & 0.00641 & $0.00018 * * *$ \\
\hline$E_{\mathrm{i}}^{m / h}$ & Maternal high education & 0.03182 & 0.02007 & 0.11296 \\
\hline$E_{i}^{p p}$ & Paternal primary education & -0.00448 & 0.00855 & 0.71178 \\
\hline$E_{i}^{p m}$ & Paternal middle education & -0.02044 & 0.00868 & $0.0185 * *$ \\
\hline$E_{i}^{p h}$ & Paternal high education & -0.04422 & 0.01496 & $0.00312 * * *$ \\
\hline$L_{\mathrm{i}}$ & Own livestock & 0.06330 & 0.00930 & $0.01578^{* *}$ \\
\hline$D R_{\mathrm{i}}$ & Dependency ratio & 0.12230 & 0.01107 & $0.0000 * * *$ \\
\hline$W_{i}$ & Wealth index & 0.00033 & 0.00160 & 0.83564 \\
\hline$C_{\hat{\mathbb{I}}}$ & Own cultivation & 0.12236 & 0.00932 & $0.0000 * * *$ \\
\hline
\end{tabular}

Significance codes: $1 \%$ '***' $5 \%$ '**' $10 \%$ '*’

Table 5 shows the coefficients of second coordinate i.e. carbohydrate shares vs geometric mean of fat and protein shares. $1 \%$ increase of income for a given household results into decline of carbohydrate share $\left(e^{0.2101}=1.2289\right)$ approximately by 0.233 with respect to geometric mean of other fat and protein shares. The second ILR coordinate 
shows that the households with high income have low proportion of carbohydrate share in calories than other shares. Household size shows positive impact while dependency ratio shows inverse impact on the relative dominance of carbohydrate share versus fat and protein share in energy intake.

Table 5. Results of compositional regression model in ILR coordinate for carbohydrate versus other shares

$S_{2}^{*}=\frac{2}{\sqrt{6}} \log \frac{S_{C}}{\sqrt{S_{P} S_{F}}}$ (carbohydrate versus geometric mean of protein and fat shares) is response variable

\begin{tabular}{|c|c|c|c|c|}
\hline Variables & Description & Coefficients & S. E. & P-value \\
\hline \multicolumn{2}{|r|}{ Intercept } & 2.112 & 0.4588 & $0.0000 * * *$ \\
\hline$A g e_{i}^{\text {hn }}$ & Age of household head & 0.00004 & 0.00021 & 0.81611 \\
\hline $\operatorname{Size}_{\mathrm{i}}$ & Household size & 0.00779 & 0.00094 & $0.0000 * * *$ \\
\hline $\operatorname{Res}_{i}$ & Residential status & 0.05770 & 0.00605 & $0.0000 * * *$ \\
\hline $\operatorname{Mar}_{\mathrm{i}}^{H}$ & HH marital status & -0.00866 & 0.00831 & 0.29747 \\
\hline$P_{\mathrm{i}}^{\mathrm{hp}}$ & KPK province & -0.01009 & 0.00952 & 0.28891 \\
\hline$P_{i}^{p}$ & Punjab province & -0.11390 & 0.00878 & $0.0000 * * *$ \\
\hline$P_{i}^{S}$ & Sindh province & -0.06990 & 0.00914 & $0.0000 * * *$ \\
\hline$I_{\tilde{i}}$ & Monthly income of household & -0.21010 & 0.00910 & $0.0000 * * *$ \\
\hline$E M_{i}^{e}$ & Couple paid employment & 0.04965 & 0.01598 & $0.001887 * * *$ \\
\hline$E M_{i}^{m}$ & Maternal paid employment & -0.01281 & 0.01290 & 0.32031 \\
\hline$E M_{i}^{p}$ & Paternal paid employment & 0.01922 & 0.00583 & $0.000354^{* * *}$ \\
\hline$E_{i}^{m p}$ & Maternal primary education & 0.01062 & 0.00622 & 0.18785 \\
\hline$E_{i}^{m m}$ & Maternal middle education & 0.00791 & 0.00689 & 0.25144 \\
\hline$E_{i}^{\min }$ & Maternal high education & 0.00363 & 0.01935 & $0.060564 *$ \\
\hline$E_{i}^{p p}$ & Paternal primary education & -0.01280 & 0.00921 & 0.16414 \\
\hline$E_{i}^{p m}$ & Paternal middle education & -0.04318 & 0.00933 & $0.0000 * * *$ \\
\hline$E_{i}^{p h}$ & Paternal high education & -0.06311 & 0.01608 & $0.00087 * * *$ \\
\hline$L_{\mathrm{i}}$ & Own livestock & 0.02518 & 0.02958 & 0.39450 \\
\hline$D R_{\mathrm{i}}$ & Dependency ratio & -0.03912 & 0.01190 & $0.00101 * * *$ \\
\hline$W_{i}$ & Wealth index & -0.00197 & 0.00172 & 0.25016 \\
\hline$C_{i}$ & Own cultivation & -0.00198 & 0.00990 & 0.84250 \\
\hline
\end{tabular}

Significance codes: $1 \%$ '***' $5 \%$ '**' $10 \%$ ' $*$ '

Coefficient estimate of residential status shows that the rural households compared to urban households have more dominance of carbohydrate share than fat and protein shares. Results show positive impact of couple paid employment and Household head paid employment on carbohydrate shares versus fat and protein shares. The relative dominance of carbohydrate share for households having couple and Household head paid employment $\left(e^{0.0496}=1.05\right.$ and $\left.e^{0.0192}=1.02\right) 1.05$ and 1.02 times larger than other households respectively. 
In second ILR coordinates, the negative coefficients show that the dominance of carbohydrate share for Province Punjab and Sindh 1.12 and 1.07 times less than base category Baluchistan province respectively. The households which lie in the province Punjab and Sindh have less carbohydrate shares proportion in calories than base category Baluchistan. Hence these two provinces have more proportion of protein and fat shares than carbohydrate shares. The effect of educational dummy variables like middle and high education of household head on carbohydrate shares is not useful. The dominance of carbohydrate shares compares to other shares for these variables is less than households which do not have an education.

\section{Elasticities of macronutrients shares}

Elasticity is very popular tool to overcome the difficult interpretation of coefficients in ILR regression. For regressors $\mathrm{X}$, the elasticity of response variable $\mathrm{Y}$ calculates the change rate between two values of response variable $\mathrm{Y}$.

To link these findings with the existing previous studies, we also use standard classical linear regression model to explain the shares of macronutrients by same household characteristics than in the model (1) as estimated separately for each share of macronutrients using ordinary least square (OLS).

$$
S_{j i \mathrm{i}}=a_{0, j}+\sum_{k=1}^{K} \beta_{0 j, k} X_{k i}+\varepsilon_{j, i} \quad \text { for } j=1,2,3
$$

Now elasticities of macronutrient shares define with respect to different regressors as

$$
\operatorname{Elast}\left(S_{j i,}, X_{i}\right)=\frac{\frac{\partial S_{j i j}}{S_{j i i}}}{\frac{\partial X_{i}}{X_{i}}}=\frac{\partial\left(S_{j i j}\right)}{\partial\left(X_{i}\right)}=\beta_{j, k}
$$

The elasticity is the fix term which is independent of considered households. For these households, the elasticity of the macronutrient share $s_{j}$ depends on all intakes of macronutrient shares, that is households diet balance.

Elasticities of macronutrient shares relative to income, household size, dependency Ratio and wealth index are presented in Table 6. It is clear that fat share is the most elastic income based macronutrient. The positive change rate of $1 \%$ of household's income is linked on the average to a positive change rate of $1.15 \%$ in the shares of fat, $0.47 \%$ increase in protein share, and $0.50 \%$ decrease in carbohydrate share in the total calories consumption. Similar is the case of dependency ratio which shows that as dependency ratio increases, it causes to increase the share of fat and protein with a decline in carbohydrate share. However, wealth index shows opposite effects as these are negative for fat and protein but positive for carbohydrate. Moreover, The positive change rate of $1 \%$ of family members in the household links on average to a positive change rate of $0.0028 \%$ in the share of fat whereas it agrees to a negative rate of change of $0.000466 \%$ and $0.0008877 \%$ for protein and Carbohydrate respectively. Figure 6 represents the box plot of income elasticities with respect to macronutrient shares. The lower quartiles of fat, protein and carbohydrate shares are $0.8086,0.4101$ and -0.5298 respectively. The median of fat, protein and carbohydrate shares are $0.9411,0.4572$, 0.4749 and upper quartiles are $1.1163,0.5095$ and -0.4295 respectively. 
Table 6. Elasticities of shares

\begin{tabular}{c|c|c|c|c}
\hline Shares & Income & Household size & Dependency ratio & Wealth index \\
\hline Fat & 1.1559 & 0.002804 & 0.00108 & -0.00027 \\
Protein & 0.4692 & -0.000463 & 0.04167 & -0.000183 \\
Carbohydrate & -0.5043 & -0.00087 & -0.00797 & 0.000101 \\
\hline
\end{tabular}

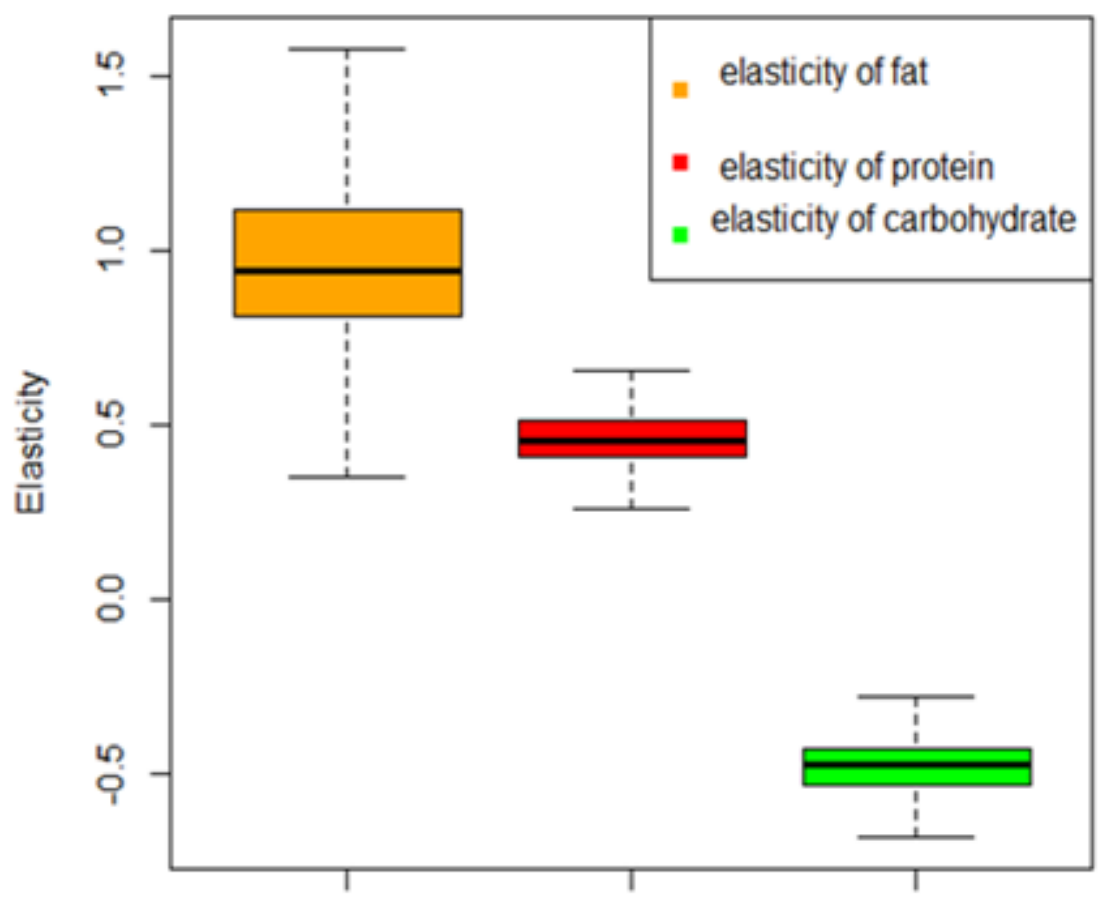

Figure 6. Box plot of income elasticities of macronutrients consumption shares

\section{Discussion}

Comparison of urban and rural households shows that there is significant difference in calorie intakes as well as in the volume of all macronutrients. The people residing in rural areas consume more calories than urban people because they are involved in heavy physical work in field, which need more energy. The results of income are consistent with the fact that the households with high income use more fatty foods than protein foods. These results are in line with the findings of Trinh et al., (2018) which shows that the fat shares in calories increase when food expenditure increase. This implies that rising household's income is not helpful to improve protein and carbohydrate shares in calories than fat shares. The results show that household size is directly related to more consumption of protein and carbohydrate compared to fat in diet. Most of the households live in rural areas which have more share of calories obtained from protein and carbohydrate than fat because they consume large amount of vegetables and dairy products like as milk, yogurt and cheese than urban.

The study explores that maternal and paternal education is not helpful in improving protein and carbohydrate shares of energy intake in Pakistan. It implies that education is playing an effective role to increase the shares of fat in calories at household level in Pakistan. In the case of Pakistan, knowledge related to nutrition and health practices is 
not part of syllabus at school or college level and therefore, most of the educated people are not aware about the concepts related to balanced food and nutrition, the food items containing macronutrients shares in calories. It implies that education without awareness of nutrition does not affect eating pattern. Moreover, estimates of all other education dummies also support the view that education is not performing well in healthy diet in term of protein and carbohydrate shares in Pakistan. The results of household head paid employment and couple paid employment dummies are not consistent with all shares of macronutrients. It implies that the healthy diet in term of macronutrient shares do not depend on paid employment of couple and household head.

\section{Conclusion and policy implementation}

CODA model is employed to evaluate the role of some important socioeconomic and demographic factors on balancing of macronutrient shares in energy consumption at household level as a case study of Pakistan. Cross sectional data of households are taken from a national level survey data, i.e. HIICS-2015-16. Household per capita income, residential status, household size, Dependency Ratio, household head and couple paid employment, Sindh dummy, middle and high educational dummies of household head also play significant role for carbohydrate shares than other shares. We may conclude that the rising income of households increases fat consumption and decreases protein and carbohydrate consumption. It implies that significant increase of households' income level will make economic access easy which may improve fat consumption in Pakistan. It induces that policy steps to raise overall households' income level on the basis of higher economic growth rate may be the most effective tool to fulfil fat requirement in healthy diet. Household size and rural residence are key factors for increasing fat shares than other shares. Hence, effective family planning strategies and birth control programs must be implemented in order to improve fat shares. Paternal education is another important factor for increasing fat shares and the low educational level leads to a reduction in protein and carbohydrate consumption. It implies that education is not playing an important role for protein and carbohydrate shares in balance diet. It is because diet related topics are not part of syllabus in education system of Pakistan and even educated people are not aware of the importance of healthy diet. Hence, it is strongly recommended that the topics of nutrition and balance diet along with its all health related impacts must be included as part of syllabus at primary and secondary education levels in order to make awareness of educated parents as well as children. The livestock and own cultivation cause to improve protein shares. Hence, development of agricultural sector and live stock is imperative to tackle the problem of protein shares in balanced diet in Pakistan

We calculated and compared the elasticities of macronutrient shares using income, household size, dependency ratio and wealth index. Our findings support to the existing literature, the most elastic macronutrient is fat share with respect to the income, household size and dependency ratio compared to other shares. But the carbohydrate share is negatively elastic to income, household size and dependency ratio. Moreover, for example the positive elasticity of macronutrient shares with respect to income represent that the positive impact of income on macronutrient shares.

In this study the important results are very helpful to support the previous studies about the development of nutritional diets at the national level. There is strong correlation between nutritional change and the non-communicable diseases risk factor 
such as heart diseases an obesity (Bloom et al., 2012), country level strategies are required to help Pakistani people to recover their pattern of diet with respect to macronutrients.

In additional research, same kind of studies which based on dietary shares of macronutrients can be done for other countries to see the entire food consumption pattern. Moreover, focusing on the association between macronutrient shares in calories and non-communicable diseases as obesity and heart diseases at the country level will be very interesting.

\section{REFERENCES}

[1] Ahluwalia, N., Ferrières, J., Dallongeville, J., Simon, C., Ducimetière, P., Amouyel, P., Arveiler, D., Ruidavets, J. B. (2009): Association of macronutrient intake patterns with being overweight in a population-based random sample of men in France. - Diabetes \& Metabolism 35(2): 129-136.

[2] Aitchison, J. (1982): The statistical analysis of compositional data. - Journal of the Royal Statistical Society: Series B (Methodological) 44(2): 139-60.

[3] Aitchison, J. (1986): CODA: A Microcomputer Package for the Statistical Analysis of Compositional Data. - Chapman and Hall, London.

[4] Akerele, D., Kebiru Ibrahim, M., Adewuyi, S. (2014): Socioeconomic determinants of protein and calorie consumption and potential risk of protein-energy malnutrition among households in South-West Nigeria. - International Journal of Social Economics 41(1): $75-88$.

[5] Austin, G. L., Ogden, L. G., Hill, J. O. (2011): Trends in carbohydrate, fat, and protein intakes and association with energy intake in normal-weight, overweight, and obese individuals: 1971-2006. - The American Journal of Clinical Nutrition 93(4): 836-843.

[6] Bloom, D. E., Cafiero, E., Jané-Llopis, E., Abrahams-Gessel, S., Bloom, L. R., Fathima, S., O'Farrell, D. (2012): The Global Economic Burden of Noncommunicable Diseases. Program on the Global Demography of Aging (No. 8712). - World Economic Forum, Geneva.

[7] Carreiro, A. L., Dhillon, J., Gordon, S., Higgins, K. A., Jacobs, A. G., McArthur, B. M., Redan, B. W., Rivera, R. L., Schmidt, L. R., Mattes, R. D. (2016): The macronutrients, appetite, and energy intake. - Annual Review of Nutrition 36: 73-103.

[8] Chen, J., Zhang, X., Li, S. (2017): Multiple linear regression with compositional response and covariates. - Journal of Applied Statistics 44(12): 2270-2285.

[9] Claro, R. M., Levy, R. B., Bandoni, D. H., Mondini, L. (2010): Per capita versus adultequivalent estimates of calorie availability in household budget surveys. - Cadernos de Saude Publica (26): 2188-2195.

[10] Dumuid, D., Stanford, T. E., Martin-Fernández, J. A., Pedišić, Ž., Maher, C. A., Lewis, L. K., Hron, K., Katzmarzyk, P. T., Chaput, J. P., Fogelholm, M., Hu, G. (2018): Compositional data analysis for physical activity, sedentary time and sleep research. Statistical Methods in Medical Research 27(12): 3726-3738.

[11] Egozcue, J. J., Pawlowsky-Glahn, V., Mateu-Figueras, G., Barcelo-Vidal, C. (2003): Isometric logratio transformations for compositional data analysis. - Mathematical Geology 35(3): 279-300.

[12] Egozcue, J. J., Daunis-I-Estadella, J., Pawlowsky-Glahn, V., Hron, K., Filzmoser, P. (2011): Simplicial regression. The normal model. - Journal of Applied Probability and Statistics 6(1): 87-108.

[13] Institute of Medicine (2005): Dietary Reference Intakes for Energy, Carbohydrate, Fiber, Fat, Fatty Acids, Cholesterol, Protein, and Amino Acids (Macronutrients). - National Academy Press, Washington, DC. 
[14] Iyangbe, C. O., Orewa, S. I. (2009): Determinants of daily protein intake among rural and low-income urban households in Nigeria. American-Eurasian. - Journal of Scientific Research 4(4): 290-301.

[15] Khan, M. A., Khan, M. A., Planning Commission (2001): Food Composition Table for Pakistan. Peshawar. - University of Agriculture, Peshawar.

[16] Khattak, M. M. A. K., Khan, M. N. (2009): Deficient intakes of energy and macronutrients in Pakistani female students assessed by composite. - Asian. J. Clin. Nutr 1: 97-101.

[17] Kushner, R. F., Doerfler, B. (2008): Low-carbohydrate, high-protein diets revisited. Current Opinion in Gastroenterology 24(2): 198-203.

[18] Leite, M. L. C. (2016): Applying compositional data methodology to nutritional epidemiology. - Statistical Methods in Medical Research 25(6): 3057-3065.

[19] Liaskos, G., Lazaridis, P. (2003): The demand for selected food nutrients in Greece: the role of socioeconomic factors. - Agricultural Economics Review 4(389-2016-23385): 93106.

[20] Mert, M. C., Filzmoser, P., Endel, G., Wilbacher, I. (2018): Compositional data analysis in epidemiology. - Statistical Methods in Medical Research 27(6): 1878-1891.

[21] Miller, W. C., Lindeman, A. K., Wallace, J., Niederpruem, M. (1990): Diet composition, energy intake, and exercise in relation to body fat in men and women. - The American Journal of Clinical Nutrition 52(3): 426-430.

[22] Morais, J., Thomas-Agnan, C., Simioni, M. (2018): Using compositional and Dirichlet models for market share regression. - Journal of Applied Statistics 45(9): 1670-1689.

[23] Muller, I., Hron, K., Fiserova, E., Smahaj, J., Cakirpaloglu, P., Vancáková, J. (2016): Interpretation of compositional regression with application to time budget analysis. arXiv 1609.07887.

[24] National Institute of Population Studies (NIPS) [Pakistan] ICF International (2013): Pakistan Demographic and Health Survey 2012-13. - NIPS, Pakistan.

[25] Ng, M., Fleming, T., Robinson, M., Thomson, B., Graetz, N., Margono, C., Mullany, E. C., Biryukov, S., Abbafati, C., Abera, S. F., Abraham, J. P. (2014): Global, regional, and national prevalence of overweight and obesity in children and adults during 1980-2013: a systematic analysis for the Global Burden of Disease Study 2013. - The Lancet 384(9945): 766-781.

[26] Nguyen, T. H. A., Laurent, T., Thomas-Agnan, C., Ruiz-Gazen, A. (2018): Analyzing the impacts of socio-economic factors on French departmental elections with CODA methods. - TSE Working Paper n. 18-961, October 2018.

[27] Olaf, M., Michael, K. (2005): Malnutrition and health in developing countries. Canadian Medical Association Journal 173(3): 279-286.

[28] Pawlowsky-Glahn, V., Buccianti, A. (2011): Compositional Data Analysis. - Wiley, London.

[29] Pawlowsky-Glahn, V., Egozcue, J. J., Tolosana-Delgado, R. (2015): Modeling and Analysis of Compositional Data. - John Wiley \& Sons, New York.

[30] Satia-Abouta, J., Patterson, R. E., Schiller, R. N., Kristal, A. R. (2002): Energy from fat is associated with obesity in US men: results from the Prostate Cancer Prevention Trial. Preventive Medicine 34(5): 493-501.

[31] Satti, M. N., Khalid, M. (2019): Prevalence and Determinants of Overweight and Obesity Among Adults in Pakistan. - Population \& Health Working Paper Series PIDE-CPHSP2. Pakistan Institute of Development Economics Islamabad.

[32] Shabnam, N., Santeramo, F. G., Asghar, Z. Seccia, A. (2016): The impact of food price crises on the demand for nutrients in Pakistan. - Journal of South Asian Development 11(3): 305-327.

[33] Shakoor, H., Khan, S., Samiullah, M., Zeb, F., Iqbal, U., Khattak, F. H. (2017): nutritional status and dietary intake of boarder female students of the University of Agriculture, Peshawar, Pakistan. - Khyber Medical University Journal 9(2). 
[34] Sheet, P. (2012): Nutrition at the World Food Programme. - World Food Programme, Rome.

[35] Smith, L. C., Haddad, L. J. (2000): Explaining Child Malnutrition in Developing Countries: A Cross-Country Analysis (Vol. 111). - Intl Food Policy Res Inst, Washington, DC.

[36] Swinburn, B. A., Sacks, G., Hall, K. D., McPherson, K., Finegood, D. T., Moodie, M. L., Gortmaker, S. L. (2011): The global obesity pandemic: shaped by global drivers and local environments. - The Lancet 378(9793): 804-814.

[37] Tanzil, S., Jamali, T. (2016): Obesity, an emerging epidemic in Pakistan-a review of evidence. - J Ayub Med Coll Abbottabad 28(3): 597.

[38] Trinh, H. T., Morais, J., Thomas-Agnan, C., Simioni, M. (2018): Relations between socio-economic factors and nutritional diet in Vietnam from 2004 to 2014: new insights using compositional data analysis. - Statistical Methods in Medical Research 28(8): 2305-2325.

[39] UNICEF (1991): Conceptual Framework of the Causes of Malnutrition. - UNICEF, New York.

[40] Van den Boogaart, K. G., Tolosana-Delgado, R. (2013): Analyzing Compositional Data with R. - Springer, Heidelberg.

[41] World Health Organization (2010): Global Status Report on Noncommunicable Diseases 2010: Description of the Global Burden of NCDs, Their Risk Factors and Determinants. World Health Organization, Geneva. http://www.who.int/entity/nmh/.

[42] World Health Organization (2018): World Health Statistics 2018: Monitoring Health for the SDGs, Sustainable Development Goals. - WHO, Geneva.

[43] World Health Organization Editor (2013): Global Tuberculosis Report 2013. http://www.who.int/nmh/countries/pak_en.pdf?ua=1.

[44] You, J., Imai, K. S., Gaiha, R. (2016): Declining nutrient intake in a growing China: Does household heterogeneity matter? - World Development 77: 171-191.

[45] Zhou, L., Chen, X., Lei, L. (2018): Intra-household allocation of nutrients in an opening China. - International Journal of Environmental Research and Public Health 15(4): 700. 